\title{
Prevalence of stunting, wasting and underweight in Grade 1-learners: The NW-CHILD Study
}

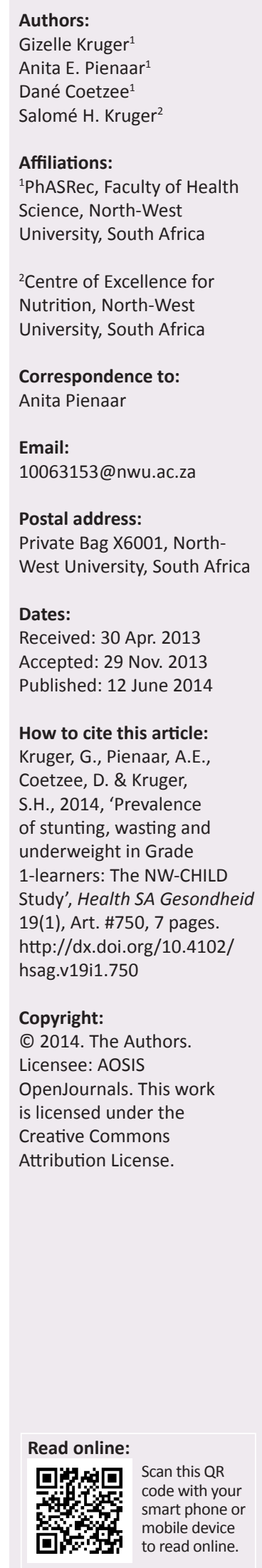

Background: Child undernutrition remains a major public health concern in developing countries, with many negative consequences to child development.

Objectives: To determine the prevalence of stunting, wasting and underweight amongst Grade 1-learners in the North West Province (NWP) of South Africa (SA), taking into account gender, race and school type.

Method: Eight hundred and sixteen (419 boys, 397 girls) learners participated in the study (567 black, 218 white, 31 other races). Underweight, stunting and wasting (Weight-for-age, height-for-age, BMI-for-age) were determined using the $z$-scores of the 2007 WHO reference sample (-2 SD).

Results: A higher prevalence of wasting and underweight were found amongst the boys $(8.35 \% ; 5.97 \%)$ compared with the girls $(6.30 \% ; 2.52 \%)$, although this was only significant for underweight $(p=0.02)$, whilst stunting percentages were very similar amongst girls $(4.53 \%)$ and boys $(4.06 \%)$. Underweight was the highest in the black group $(5.47 \% ; p<0.01)$, compared with the white group $(0.46 \%)$ and the prevalence of the conditions is associated with school types which represent low socio-economic circumstances (Quintile 1-3 schools). Only black learners showed stunting $(p<0.01)$ and more black learners were wasted $(n=39)$ compared with white $(n=15 ; p=0.08)$ learners. Quintile $1-3$ schools had a significantly higher prevalence of underweight $(5.14 \%-8.18 \%)$ and stunting $(3.88 \%-10.7 \%)(p<0.01)$ compared with Quintile 4 and 5 schools.

Conclusion: The prevalence of stunting, wasting and underweight need improvement amongst school beginners, especially in Quintile 1-3 type schools but also amongst black learners living in the NWP of SA as it can have significant hampering effects on the future development and well-being of children.

Agtergrond: Ondervoeding is steeds ' $n$ publieke gesondheidsgevaar by kinders in ontwikklende lande, met heelwat negatiewe gevolge vir kinderontwikkeling.

Doel: Om te bepaal wat die voorkoms van groei-inperking, ondervoeding en ondergewig by Graad 1-leerders in die Noordwes-Provinsie (NWP) van Suid-Afrika (SA) is, met in ag neming van geslag, ras en skooltipe.

Metode: Agt honderd en sestien leerders (419 seuns; 397 meisies) is ewekansig geselekteer vir deelname aan die studie (567 swart, 218 wit, 31 ander rasgroepe). Ondergewig, groei-inperking en ondervoeding is bepaal deur $z$-tellings vir massa-vir-ouderdom, lengte-vir-ouderdom en LMI-vir-ouderdom volgens die 2007 WHO verwysings (-2 SA).

Resultate: 'n Hoër voorkoms vir ondervoeding en ondergewig is by seuns (8.35\%; 5.97\%) teenoor meisies $(6.30 \% ; 2.52 \%)$ gevind, alhoewel slegs betekenisvol vir ondergewig $(p=0.02)$, terrwyl persentasies van groei-inperking redelik dieselfde was by meisies $(4.53 \%)$ en seuns $(4.06 \%)$. Ondergewig het die hoogste voorkoms in die swart groep $(5.47 \% ; p<0.01)$ getoon, en die voorkoms word geassosieer met skooltipes wat lae sosio-ekonomiese omstandighede verteenwoordig. Slegs swart leerders het groei-inperking getoon $(p<0.01)$ en meer swart leerders was ondervoed $(n=39)$ teenoor blanke $(n=15)$ leerders. Kwintiel $1-3$ skole het ' $n$ betekenisvolle hoër voorkoms vir ondergewig $(5.14 \%-8.18 \%)$ en groei-inperking $(3.88 \%$ $-10.7 \%)$ getoon $(p<0.01)$ as die Kwintiel 4 en 5 skole.

Gevolgtrekking: Groei-inperking, ondervoeding en ondergewig moet by skoolbeginners verbeter word, veral in Kwintiel 1-3 skooltipes en by Swart leerlinge in die NWP van SA, veral weens die negatiewe uitwerking wat dit op die toekomstige ontwikkeling en welstand van leerders wat daaronder gebuk gaan, kan uitoefen.

\section{Introduction}

In developing countries, child undernutrition remains a major public health concern (United Nations Children's Fund [UNICEF] 2012:20). The World Health Organization (WHO 2000) 
states that undernutrition is the most important risk factor globally for developing illness and mortality. Insufficient nutrition is one of a wide range of interlinked factors forming the so-called 'poverty syndrome' (UNICEF 2012:20). The WHO (WHO 2005) defines undernutrition as the cellular imbalance between the supply of nutrients and energy and the body's ability to utilise it for growth and the maintenance of specific functions, including resistance to infections and recovery from illness. Abnormalities in growth are indicators of undernutrition because feeding status reflects growth amongst children (Robinson et al. 2001:287). Malnutrition, which is related to macronutrient deficiency, is characterised by stunting, wasting or thinness and underweight. Underweight is defined as insufficient weight for age; stunting is defined as insufficient height for age; and wasting or thinness as insufficient mass for height (Victora 1991:1105). Thinness is also considered to be equivalent to body mass index (BMI)-for-age (De Onis et al. 2006:943). Saloojee and Pettifor (2012:383) report that underweight and stunting, which are considered to be moderate forms of malnutrition are, in households in South Africa (SA), mainly the result of poor feeding practices over a long period coupled by an increased incidence of infections, rather than a lack of food.

More than half of all deaths amongst children worldwide are caused by undernutrition (WHO 2005). In 2001, undernutrition was responsible for $54 \%$ of all child deaths (WHO 2005). Underweight was the cause of 3.4 million deaths worldwide in 2000, of which 1.8 million were in Africa (WHO 2005). An anthropometric study conducted in SA in 2005 on children aged between 1 and 9, indicated that $20.7 \%$ were stunted, $8.1 \%$ were underweight and $5.8 \%$ were wasted (Kruger et al. 2012:594). A study in the magisterial district of KwaZulu-Natal, looking at 579 primary school children between the ages of 8 and 10, reported that $7.3 \%$ of them suffered from stunting (Jinabhai et al. 2001:50).

Undernutrition contributes to serious developmental problems amongst children. Researchers report a relationship between stunting and problems in cognitive abilities (Brown \& Pollitt 1996:38; Scrimshaw 1998:368; Victora et al. 2008:340), scholastic achievement (Mendez \& Adair 1999:1555; Victora et al. ibid:343) and early school failure (Victora et al. ibid:340; Walton \& Allen 2011:418). Apart from the physical problems, undernutrition is also associated with negative psychological development (Saunders, Smith \& Stroud 2011:47). Children suffering from undernutrition also manifest various behavioural changes and sometimes appear irritated, apathetic, attention deficient, anxious and have a lowered social response (Shashidhar \& Grigsby 2009:4). Gross motor skills, including speed and coordination, as well as fine motor skills, are influenced negatively by undernutrition (Chopra \& Sharma 1992:9). Undernutrition also results in negative health conditions in which every organ system in the human body is affected (Saunders et al. ibid:46; Shashidhar \& Grigsby 2009:1). Children suffering from undernutrition are also more susceptible to illness (Torpy, Lynm \& Glass 2004:648). Motor, cognitive and physical development are some of the main areas of a young child's vast developmental needs (Pienaar 2009:49), all of which are affected by undernutrition.
From the aforementioned literature it appears that undernutrition is a worldwide problem amongst children. The prevalence of malnutrition in adolescents is considerably less than those in children and relatively few studies have been carried out on this topic with school-age populations (Prista et al. 2003:956). At present, there is a shortage of literature relating to the undernutrition profiles of schoolbeginners in South Africa, as indicated by stunting, wasting and underweight. It is, however, important to obtain more information regarding the prevalence of stunting, wasting and underweight in school-beginners, since undernutrition plays an important role in various aspects of children's development, as already indicated. The aims thus arising from the above are firstly, to determine the current status of stunting, wasting and underweight amongst Grade 1-learners in the North West Province of South Africa and, secondly, to determine whether this status is related to gender, race and school type.

\section{Research method and design}

\section{Sample size and sampling procedure}

The research formed part of the NW-CHILD (Child Health Integrated Learning and Development) study. Grade 1-learners in the North West Province of South Africa served as the target population for the study. The total number of participants selected for inclusion in the study was 880 Grade 1-learners. The participants were selected randomly by means of stratification by district and gender. To determine the research group, a list of names of public schools in the North West Province was obtained from the Department of Basic Education. From the list of schools in the North West Province, which are grouped in eight education districts, each representing 12-22 regions, with approximately 20 schools (minimum 12, maximum 47) per region, districts and schools were selected randomly with regard to population density and school status (Quintile 1, i.e. schools from very poor economic sectors to Quintile 5, i.e. schools from very good economic sectors). Twenty schools, from four districts with a minimum of 40 children per school and with an even gender distribution, were involved in the study. The total group that participated consisted of 816 learners (419 boys and 397 girls) with a mean age of 6.78 years (6.0-7.67 years) and an ethnic distribution of 567 black (69.5\%), 218 white (26.7\%), 20 Mixed-race (2.5\%) and 11 Indian (1.3\%) learners. Sixty-four of the selected children were not tested. The parents of $13(1.5 \%)$ of the children did not consent for them to participate, whilst the rest were absent from school on the day of testing or had to be excluded because of incorrect ages being provided by the schools.

\section{Ethical considerations}

Ethical approval for the execution of the study was obtained from the Ethics Committee of the NWU (No. 0007009 A1). Permission was also obtained from the Department of Basic Education of the North West Province.

It was indicated in the informed consent letter that participation was voluntary, with participants having the right to withdraw at any stage of the study. 


\section{Anthropometry measurements}

The anthropometric measurements included height $(\mathrm{cm})$ and body mass $(\mathrm{kg})$. These variables were measured by trained postgraduate students in Human Movement Sciences specialising in Kinderkinetics in accordance with the protocol of the International Society for the Advancement of Kinanthropometry (ISAK 2006:137). Two height measurements were taken by means of a portable stadiometer to the nearest $0.1 \mathrm{~cm}$ whilst standing barefoot and the mean of the two measurements was taken. Body mass was measured with an electronic scale (BF 511, Omron) to the nearest $0.1 \mathrm{~kg}$. From the height and body mass measurements the body mass index (BMI) $\left(\mathrm{kg} / \mathrm{m}^{2}\right)$ was calculated for each participant.

\section{Determination of $z$-scores}

The WHO (WHO 2007) reference data were used as a standard to determine the $z$-scores for height-for-age (HAZ), BMI-for-age (BMIZ) and weight-for-age (WAZ). Z-scores of less than -2 standard deviation (SD) for height-for-age and weight-for-age were used to determine the prevalence of stunting and underweight. The $z$-score for wasting was determined using BMI-for-age, under the 5th percentile from the International reference population (De Onis et al. 2006:943). In addition to BMI for age, a $z$-score of less than -2 standard deviation (SD) for weight-for-height was also used to calculate wasting. Larger negative $z$-scores indicate higher levels of undernutrition.

\section{Data analysis}

Statistica (StatSoft 2011) and the WHO AnthroPlus software (version 1.0.2, 2010) in SAS (Statistical Analysis System) were used to analyse the data. For the purpose of description, data were analysed using means and percentages. Z-scores were determined for the classification of stunting, wasting and underweight. The Pearson chi-square $p \leq 0.05$ was used to determine the statistical significance of differences in stunting, wasting and underweight between school types, race and genders. For the interpretation of practical significance, $\varphi \geq 0.1$ indicates a small magnitude of effect, $\varphi \geq 0.3$ indicates a medium effect and $\varphi \geq 0.5$ indicates a large effect (Cohen 1988:20). For the interpretation of practical significance, the phi coefficient $(\varphi)$ is used as a measure of the strength of this association, where $\varphi=0.1$ indicates a small magnitude of effect, $\varphi=0.3$ indicates a medium effect and $\varphi$ $=0.5$ indicates a large effect (Cohen 1988:20). Because of the small number of mixed-race and Indian children that entered the sample, these children $(n=31)$ were excluded from the racial analyses.

\section{Results}

Table 1 displays descriptive statistics of the number and gender of the black and white children in the different school types. Table 1 indicates that most of the black children $(n=$ $567)$ attended Quintile 1 to 3 schools $(n=470)$, whilst all white children attended Quintile $4(n=85)$ and $5(n=133)$ schools. Slightly more white boys ( $n=123)$ as opposed to white girls $(n=95)$ and more black girls $(n=288)$ as opposed to black boys $(n=279)$ participated in the study.

Table 2 shows that 35 participants (4.29\%) in the group were stunted (HAZ), with a mean $z$-score of -2.35 . Wasting (BMIZ) was more prevalent, with 60 participants $(7.35 \%)$ displaying wasting (mean $z$-score $=-2.04$ ). Table 2 further indicates that 35 participants $(4.29 \%)$ were underweight (WAZ), with a mean $z$-score of -2.39 .

Table 3 displays the number and percentage of boys and girls who were stunted, wasted and underweight respectively. No significant differences were found in stunting between the genders $(p=0.74 ; \varphi=0.01)$, where only $4.06 \%(n=17)$ of boys and $4.53 \%(n=18)$ of girls were stunted. A higher percentage of boys showed wasting $(n=35 ; 8.35 \%)$ compared with girls ( $n=25 ; 6.3 \%)$, although the difference was also insignificant. A statistically-significant difference ( $p=0.02)$ was, however, found between boys $(n=25 ; 5.97 \%)$ and girls $(n=10 ; 2.52 \%)$ who were underweight, although the difference was not practically significant $(\varphi=0.08)$.

Table 4 indicates the number and percentage of white and black participants who were stunted, wasted and underweight. Statistically- $(p \leq 0.01)$ and practically$(\varphi=0.13)$ significant differences were found in the percentages of stunting between white and black children, where $6.0 \%$ $(n=34)$ of black children were stunted as opposed to no white children. A borderline significant difference was found for wasting amongst the racial groups ( $p=0.08)$, with $39(6.88 \%)$ of the black children and $15(6.88 \%)$ of the white group being wasted. The difference was however, practically significant $(\varphi=0.13)$. Statistically- $(p \leq 0.01)$ and practically- $(\varphi=0.11)$ significant differences were also found amongst the white and black groups for underweight, where $5.47 \%(n=31)$ of black children and $0.46 \%(n=1)$ of white children were underweight.

TABLE 1: Distribution of participants by school type, gender and race $(N=785)$.

\begin{tabular}{|c|c|c|c|c|c|c|c|c|c|c|}
\hline \multirow[t]{3}{*}{ Variables } & \multicolumn{5}{|c|}{ White children } & \multicolumn{5}{|c|}{ Black children } \\
\hline & \multicolumn{2}{|c|}{ Boys } & \multicolumn{2}{|c|}{ Girls } & \multirow{2}{*}{$\begin{array}{c}\text { Total } \\
N \\
\end{array}$} & \multicolumn{2}{|c|}{ Boys } & \multicolumn{2}{|c|}{ Girls } & \multirow{2}{*}{$\frac{\text { Total }}{N}$} \\
\hline & $n$ & $\%$ & $n$ & $\%$ & & $n$ & $\%$ & $n$ & $\%$ & \\
\hline Quintile 1 & 0 & 0 & 0 & 0 & 0 & 69 & 50.0 & 69 & 50.0 & 138 \\
\hline Quintile 2 & 0 & 0 & 0 & 0 & 0 & 84 & 52.8 & 75 & 47.2 & 159 \\
\hline Quintile 3 & 0 & 0 & 0 & 0 & 0 & 83 & 48.0 & 90 & 52.0 & 173 \\
\hline Quintile 4 & 51 & 60.0 & 34 & 40.0 & 85 & 27 & 45.0 & 33 & 55.0 & 60 \\
\hline Quintile 5 & 72 & 54.1 & 61 & 45.9 & 133 & 16 & 43.2 & 21 & 56.8 & 37 \\
\hline All & 123 & - & 95 & - & 218 & 279 & - & 288 & - & 567 \\
\hline
\end{tabular}


TABLE 2: Mean $z$-scores and percentage of participants with and without undernutrition characteristics.

\begin{tabular}{|c|c|c|c|c|c|c|c|c|c|}
\hline \multirow[t]{2}{*}{ Variables } & \multicolumn{3}{|c|}{ HAZ } & \multicolumn{3}{|c|}{ BMIZ } & \multicolumn{3}{|c|}{ WAZ } \\
\hline & Mean & $n$ & $\%$ & Mean & $n$ & $\%$ & Mean & $n$ & $\%$ \\
\hline \multicolumn{10}{|l|}{ Normal } \\
\hline Boys & -0.12 & 402 & 95.94 & -0.16 & 384 & 91.65 & -0.17 & 394 & 94.03 \\
\hline Girls & -0.15 & 379 & 95.47 & -0.12 & 372 & 93.7 & -0.15 & 387 & 97.48 \\
\hline Black & -0.43 & 533 & 94.0 & -0.24 & 528 & 93.12 & -0.41 & 536 & 94.53 \\
\hline White & -0.69 & 218 & 100.0 & -0.16 & 203 & 93.12 & -0.54 & 217 & 99.54 \\
\hline Quintile 1 & -0.45 & 149 & 96.13 & -0.22 & 142 & 91.61 & -0.41 & 147 & 94.84 \\
\hline Quintile 2 & -0.69 & 142 & 89.31 & -0.30 & 148 & 93.08 & -0.63 & 146 & 91.82 \\
\hline Quintile 3 & -0.45 & 167 & 95.43 & -0.48 & 163 & 93.14 & -0.58 & 166 & 94.86 \\
\hline Quintile 4 & -0.49 & 151 & 98.05 & -0.04 & 139 & 90.26 & -0.37 & 150 & 97.40 \\
\hline Quintile 5 & -0.42 & 172 & 99.42 & -0.26 & 164 & 94.80 & -0.45 & 172 & 99.42 \\
\hline All & -0.14 & 781 & 95.71 & -0.14 & 756 & 92.65 & -0.16 & 781 & 95.71 \\
\hline \multicolumn{10}{|c|}{ Undernutrition } \\
\hline All & -2.35 & 35 & 4.29 & -2.04 & 60 & 7.35 & -2.39 & 35 & 4.29 \\
\hline
\end{tabular}

HAZ, Height-for-age-z-score; BMIZ, BMI-for-age-z-score; WAZ, Weight-for-age-z-score.

$H A Z$, stunting; BMIZ, wasting; WAZ, underweight.

TABLE 3: Differences in number and percentage of boys and girls with undernutrition characteristics.

\begin{tabular}{|c|c|c|c|c|c|c|}
\hline \multirow[t]{2}{*}{ Variable } & \multicolumn{2}{|c|}{ Boys } & \multicolumn{2}{|c|}{ Girls } & \multicolumn{2}{|c|}{ Significance in differences } \\
\hline & $n$ & $\%$ & $n$ & $\%$ & $p$ & $\varphi$ \\
\hline \multicolumn{7}{|l|}{$H A Z<-2$} \\
\hline Stunting & 17 & 4.06 & 18 & 4.53 & 0.74 & 0.01 \\
\hline \multicolumn{7}{|l|}{ BMIZ $<-2$} \\
\hline Wasting & 35 & 8.35 & 25 & 6.3 & 0.30 & -0.04 \\
\hline \multicolumn{7}{|l|}{$W A Z<-2$} \\
\hline Underweight & 25 & 5.97 & 10 & 2.52 & $0.02 *$ & 0.08 \\
\hline
\end{tabular}

HAZ, Height-for-age-z-score; BMIZ, BMI-for-age-z-score; WAZ, Weight-for-age-z-score. $*, p \leq 0.05 ; \varphi$-value, practical significance where $\varphi \geq 0.1$ small, $* *, \varphi \geq 0.3$ medium; ${ }^{* * *}, \varphi \geq$ 0.5 large indicate significance.

TABLE 4: Differences in number and percentage of white and black participants with undernutrition characteristics.

\begin{tabular}{|c|c|c|c|c|c|c|}
\hline \multirow{2}{*}{ Variables } & \multicolumn{2}{|c|}{ White children } & \multicolumn{2}{|c|}{ Black children } & \multicolumn{2}{|c|}{ Significance in differences } \\
\hline & $n$ & $\%$ & $n$ & $\%$ & $p$ & $\varphi$ \\
\hline \multicolumn{7}{|l|}{$H A Z<-2$} \\
\hline Stunting & 0 & 0.0 & 34 & 6.0 & $<0.01 *$ & $0.13^{*}$ \\
\hline \multicolumn{7}{|l|}{$\mathrm{BMIZ}<-2$} \\
\hline Wasting & 15 & 6.88 & 39 & 6.88 & 0.08 & $0.13^{*}$ \\
\hline \multicolumn{7}{|l|}{$W A Z<-2$} \\
\hline Underweight & 1 & 0.46 & 31 & 5.47 & $<0.01 *$ & $0.11^{*}$ \\
\hline
\end{tabular}

$\mathrm{HAZ}$, Height-for-age-z-score; BMIZ, BMI-for-age-z-score; WAZ, Weight-for-age-z-score. $*, p \leq 0.05$; $\varphi$-value, practical significance where $\varphi \geq 0.1$ small; $* *, \varphi \geq 0.3$ medium; ***, $\varphi \geq 0.5$ large indicate significance.

Table 5 describes the number and percentage of stunting, wasting and underweight that were found, related to school type. Statistically-significant differences $(p<0.01)$ were found between the percentages of stunting in the Quintile 1-3 schools compared with Quintile 4 and 5 schools, where the Quintile 1-3 schools had the highest stunting percentages $(3.88 \%-10.70 \%)$ compared with Quintile 4 and 5 schools. The highest prevalence of wasting was found in the Quintile 4 schools $(n=15)(9.74 \% ; p=0.59)$. Wasting varied between $5.20 \%(n=9)$ (Quintile 5) and 9.74\% $(n=15)$ (Quintile 4), whilst Quintile 1 showed 8.39\% $(n=13)$, Quintile 2, 6.92\% $(n=11)$ and Quintile 3, 6.86\% $(n=12)$. No significant differences were, however, found amongst the different Quintile schools. Table 5 furthermore reflects a statistically- $(p<0.01)$ and practically- $(\varphi=0.13)$ significant difference in the percentage underweight in Quintile 1-3 schools, compared against Quintile 4 and 5 schools, with Quintile 1-3 schools having the highest prevalence of underweight $(5.14 \%-8.18 \%)$.

\section{Validity and reliability}

The participants enjoyed taking part in the study. We found that most of them gave their best effort in the performance tests.

All efforts were made to ensure reliable results. All researchers were well qualified to do the testing and a researcher was responsible for taking measurements throughout the gathering of the data process in order to yield consistent measurements. The study is considered to have good internal validity because of the rigorous study design and the care taken in the conducting of measurements and the external validity of the results is also considered appropriate because of the generalisability of the results.

\section{Discussion}

This study aimed to determine the current status of stunting, wasting and underweight amongst Grade 1-learners in the North West Province of South Africa and then to determine whether this status is related to gender, race and/or school type - a reflection of the socio-economic circumstances in which learners grow up. The study found the following in the group: stunting $(4.29 \%)$, wasting $(7.35 \%)$ and underweight (4.29\%). These percentages agree, to some extent, with other studies conducted on a worldwide scale on children of the same group (Gray, Cossman \& Powers 2006:553; Popkin, Richards \& Montiero 1996:3013; Tarakan \& Suchindran 1999:844), in sub-Saharan Africa (Prista et al. 2003:954) and in South Africa (Coutsoudis \& Coovadia 2001:459; Jinabhai et al. 2001:50; Vorster et al. 1997:172)

Worldwide studies relating to stunting report that $15 \%$ of Brazilian children and $9.2 \%$ of Russian children $(n=4872)$ between the ages of 7 to 9 years were stunted (Popkin et al. 1996:3013), whilst a study by Gray et al. (2006:553) reported that $5.6 \%$ of children 6 years of age and $11.2 \%$ of children 7 years of age in Central Honduras were stunted. A South African study done by Jinabhai et al. (2001:50) in KwaZuluNatal, reported that $7.3 \%$ children between the ages of 8 and 
TABLE 5: Differences in proportions and percentage participants in different school types (Quintiles 1-5) with undernutrition characteristics.

\begin{tabular}{|c|c|c|c|c|c|c|c|c|c|c|c|c|}
\hline \multirow[t]{2}{*}{ Variables } & \multicolumn{2}{|c|}{ Quintiles 1} & \multicolumn{2}{|c|}{ Quintiles 2} & \multicolumn{2}{|c|}{ Quintiles 3} & \multicolumn{2}{|c|}{ Quintiles 4} & \multicolumn{2}{|c|}{ Quintiles 5} & \multicolumn{2}{|c|}{ Significance in differences } \\
\hline & $n$ & $\%$ & $n$ & $\%$ & $n$ & $\%$ & $n$ & $\%$ & $n$ & $\%$ & $p$ & $\varphi$ \\
\hline \multicolumn{13}{|l|}{$H A Z<-2$} \\
\hline Stunting & 6 & $3.88^{4,5}$ & 17 & $10.70^{4,5}$ & 8 & $4.57^{4,5}$ & 3 & $1.95^{1,2,3}$ & 1 & $0.58^{1,2,3}$ & $<0.01^{*}$ & 0.17 \\
\hline \multicolumn{13}{|l|}{ BMIZ <-2 } \\
\hline Wasting & 13 & 8.39 & 11 & 6.92 & 12 & 6.86 & 15 & 9.74 & 9 & 5.20 & 0.59 & 0.06 \\
\hline \multicolumn{13}{|l|}{$W A Z<-2$} \\
\hline Underweight & 8 & $5.17^{4,5}$ & 13 & $8.18^{4,5}$ & 9 & $5.14^{4,5}$ & 4 & $2.60^{1,2,3}$ & 1 & $0.58^{1,2,3}$ & $<0.01^{*}$ & $0.13^{*}$ \\
\hline
\end{tabular}

HAZ, Height-for-age-z-score; BMIZ, BMI-for-age-z-score; WAZ, Weight-for-age-z-score.

Significance superscript indicates significance between school types ( ${ }^{1}$ Quintile $1 ;{ }^{2}$ Quintile $2 ;{ }^{3}$ Quintile $3 ;{ }^{4}$ Quintile $4 ;{ }^{5}$ Quintile 5 ).

${ }^{*}, p \leq 0.05$; $\varphi$-value, practical significance where $\varphi \geq 0.1$ small; ${ }^{* *}, \varphi \geq 0.3$ medium; ${ }^{* *}, \varphi \geq 0.5$ indicate large significance.

10 were stunted. An overview study (1975-1996) conducted by Vorster et al. (1997:172) in South Africa over a period of 20 years regarding the nutritional status of children, indicated that the prevalence of stunting amongst primary school children decreased from $33.6 \%$ to $14.6 \%$ over this period. The results of the THUSA BANA (Transition and Health during Urbanisation of South Africans; BANA, children) study done in the North West Province by Mukuddem-Peterson and Kruger (2004:842) on 1257 children between the ages of 10 and 15 years old, showed that stunting was higher in rural areas (23.7\% girls; $26.7 \%$ boys) than urban areas $(11.6 \%$ girls; $17.1 \%$ boys). The National Food Consumption Survey (Labadarios et al. 2005:533), done on pre-school children in South Africa, indicated that 1 in 4 children was stunted and 1 in every 10 children was underweight. The lower prevalence of stunting (4.29\%) found in this study, therefore, may be an indication of a decreasing trend in stunting amongst South African primary school children. This finding also agrees with the results of Prista et al. (2003:954) on Mozambican children who indicated a decrease in the rates of stunting over the period of their study (September 1992 - June 2000), where the proportion of subjects with stunted growth dropped from $34.5 \%$ to $3 \%$ in boys and from $24.6 \%$ to $2.3 \%$ in girls. They ascribed these observed changes to socioeconomic conditions in Mozambique, where the situation changed after peace was reached in 1992 (after a period of war from 1980-1992), which led to increases in urbanisation, sedentary occupations and the advent of fast food, all of which contributed to the decline in nutritional problems in the country (Prista et al. ibid:957).

The South African primary school nutrition programme, implemented in 1994, may be one reason for the decline in stunting that was seen in our study of which all the Quintile 1-3 schools were part, as approximately 5 million children in 15000 primary schools are fed annually by this programme (Van Stuijvenberg 2005:S213). These programmes focus on relieving short-term hunger, thereby helping children to realise their full mental and physical potential and to perform optimally at school (Van Stuijvenberg ibid:S213). Another reason may be the Child Support Grant (CSG) system implemented as a measure of poverty alleviation (Triegaardt 2005:249). The CSG was first introduced in 1998 with the purpose of providing support, in the form of cash benefits, for children in poverty and this benefit increased over this period to R280 per month per child in 2012 (Triegaardt ibid:249).
Minor differences were found in the percentage of girls $(4.53 \%)$ and boys $(4.06 \%)$ that were stunted in this study. This result differs from the findings of Monyeki, Cameron and Getz (2000:42) on Ellisras children in the Limpopo province, where stunting was more prevalent amongst boys aged $6.0-6.9$ years $(7.7 \%)$ and $7.0-7.9$ years $(5.5 \%)$ than amongst girls of the same age groups $(4.1 \%$ and $3.5 \%$, respectively), as well as from the findings of Mukuddem-Peterson and Kruger (2004:842) who also reported a higher percentage poverty of boys being stunted at the ages of 10-15 years.

Stunting was also more prevalent amongst black children, with no stunting found amongst white children. Children attending schools in low socio-economic circumstances (Quintile 1-3 school types) also had the highest incidences of stunting, varying between $3.88 \%$ and $10.70 \%$. South African studies indicate in this regard that the prevalence of stunting is higher in rural areas (very low, low and medium socioeconomic circumstances) as opposed to urban areas (high and very high socio-economic circumstances) (Kruger et al. 2012:594; Monyeki et al. 2000:42). Studies from 33 countries, including Africa, also showed, on average, that stunting was 1.6 times higher in rural than urban areas (UNICEF 1998). Poverty is especially severe in the rural areas of South Africa, where percentages of $73.7 \%$ are indicated (Coutsoudis \& Coovadia 2001:459).

The prevalence of wasting that was found in this study $(7.35 \%)$ is on a par with statistics in other countries such as Botswana and Mozambique, except for a study done in Central Honduras which showed that only $0.9 \%$ of the children between the ages of 5 and 9 years suffered from wasting (Gray et al. 2006:553). In Botswana, 7.1\% of children between the ages of 0 and 6 years of age were wasted (Tharakan \& Suchindran 1999:844). A study in Mozambique reports that $21.9 \%$ boys and $10.0 \%$ girls aged between 6 and 18 years were wasted (Prista et al. 2003:952). A South African study in KwaZulu-Natal reports higher percentages amongst children aged between 3 months and 4 years, where Chopra (2003:645) reported that $12 \%$ of the children of 516 households were wasted. Wasting was also higher amongst black children $(n=39)$ than white children $(n=15)$ in our study and most of these black children were in the Quintile 1-3 schools, which typically represent lower socio-economic circumstances. Statistics show that poverty is higher than $60 \%$ amongst black populations, compared with $5 \%$ amongst white populations in South Africa (Coutsoudis \& Coovadia 2001:459), which might explain the results in this study. 
Wasting showed the highest prevalence in the Quintile 4 schools (15 learners), which was a surprising result as these schools are considered to be more affluent schools where a lower prevalence of nutritional deficiencies is expected. The participants in the study who were recruited from Quintile 4 schools comprised 85 white and 60 black children. As white participants who entered the study only attended the Quintile 4 and 5 school types, some of them might also have originated from poorer households where they also experience food insecurity. These schools, however, do not have feeding schemes, in comparison with Quintile 1-3 schools where feeding schemes are in place to ensure that children receive meals during school hours, thus contributing to their developing fewer signs of wasting. Another possibility for the higher prevalence of wasting in the higher socio-economic school types could be because lower-income parents not living in the area of the school sometimes enrol their children in schools in more affluent areas, because they believe that their children will receive a better education in that environment. The negative consequence of this is that such children might be sent to school hungry. Wasting is, however, an acute problem and childhood illnesses might also have an influence on this result (Saloojee \& Pettifor 2012:383). It is of interest to note that Prista et al. (2003:957) also found higher wasting percentages in the higher socioeconomic areas in Mozambique and could not provide an explanation for this.

The results further indicate that boys (5.73\%) were considerably more underweight than girls (2.52\%) and more black children $(5.47 \%)$ were underweight as compared with white children $(0.46 \%)$. These results correspond with research done by Reddy et al. (2008:205) on 13-19 year-old children in South Africa, where underweight was also more prevalent amongst boys (15.6\%) than girls (3.9\%) and in black (9.5\%) versus white $(1.9 \%)$ children. Reddy et al. (ibid:205) indicated that there could be several reasons for this genderracial distribution of nutritional status in South Africa, one of which could be the cultural effect of social pressure. Research done amongst children in Brazil by Reis (2012:174) showed that white children had better nutrient intakes than black children and these differences were ascribed to differences in socio-economic conditions. Underweight was furthermore most prevalent in the school types that are associated with lower socio-economic status. Quintile 2 (8.18\%) schools showed the highest prevalence, although the prevalence in Quintile 1 and 3 schools did not differ significantly (5.17\%; $5.14 \%$ ) from Quintile 2 schools. No explanation can be offered for this result. Labadarios et al. (2005:533) also found that underweight was more prevalent in the low socio-economic (rural) areas than in high socio-economic areas.

\section{Recommendations}

A possible solution could thus be to implement feeding schemes in all schools or to provide other food support to needy children in these schools. Although feeding schemes and grants are provided to needy schools and households, it is recommended that the Departments of Basic Education and Health find more strategies to address these problems as undernutrition has various negative developmental complications, including motor and cognitive delays and psychological problems, and thus ought to be addressed. The highest percentage of wasting was found in the Quintile 4 schools and it is thus recommended that the implementation of feeding schemes should also be considered in these schools. It is further recommended that longitudinal followup studies be executed in order to determine whether the problems of under nutrition persist or decrease over time. The follow-up studies can furthermore determine the longterm effect of the feeding schemes that are in place at the lower socio-economic schools.

\section{Limitations of the study}

The findings should be interpreted whilst knowing that the study had limitations as it was only conducted in one province of South Africa. However, the strength of the study is the large representative sample of children that was assessed.

\section{Conclusion}

Stunting, wasting and underweight were found in this study to be prevalent amongst Grade 1-learners in the North West Province of South Africa (stunting 4.29\%, wasting 7.35\% and underweight $4.29 \%$ ). Although direct comparisons were not possible with other studies on the same aged children, it appears that the prevalence, especially with regard to stunting, has decreased considerably when compared with other published South African studies. Stunting and underweight were also more prevalent in schools in lower socio-economic circumstances (Quintile 1-3 schools) and in black school beginners.

\section{Acknowledgements}

This work is based upon research supported by the National Research Foundation of South Africa (NRF), the National Lottery Distribution Fund and the Focus area of PhASRec, all of whom are acknowledged for their contributions.

The authors would also like to express their gratitude to the students, research teams and the schools and learners who participated in the study.

Disclaimer: any opinion, findings and conclusions or recommendations expressed in this material are the opinion of the author(s) and the NRF, therefore, do not accept any liability in this regard.

\section{Competing interests}

The authors declare that they have no financial or personal relationship(s) which may have inappropriately influenced them in writing this article.

\section{Authors' contributions}

G.K. (North-West University) was responsible for data gathering and the writing of the article as part of her dissertation; A.P. (North-West University) was the principle 
investigator on the project and the supervisor; D.C. (NorthWest University) was a co-supervisor; and H.S. Kruger (North-West University) was a critical reader and made conceptual contributions to the article.

\section{References}

Brown, J.L. \& Pollitt, E., 1996, 'Malnutrition, poverty and intellectual development', Scientific American 274(2), 38-43. http://dx.doi.org/10.1038/ development', Scientific
scientificamerican0296-38

Chopra, J.S. \& Sharma, A., 1992, 'Protein energy malnutrition and the nervous system', Journal of Neurological Sciences 110(1-2), 8-20. http://dx.doi.org/10.1016/0022510X(92)90003-4

Chopra, M., 2003, 'Risk factors for undernutrition of young children in a rural area of South Africa', Public Health Nutrition 6(7), 645-652. http://dx.doi.org/10.1079/ PHN2003477

Cohen, J., 1988, Statistical power analysis for the behavioral sciences, 2nd edn. Erlbaum, Hillsdale, NJ.

Coutsoudis, A. \& Coovadia, H.M., 2001, 'Nutrition activities in South Africa', Nutrition Research 21(1), 459-463. http://dx.doi.org/10.1016/S0271-5317(00)00262-1

De Onis, M., Onyango, A.W., Borghi, E., Garza, C. \& Yang, H., 2006, Comparison of the World Health Organization (WHO) child growth standards and the National Centre for Health Statistics/WHO international growth reference: implications for
child health programmes', Public Health Nutrition 9(7), 942-947. http://dx.doi. child health programmes',
org/10.1017/PHN20062005

Gray, V.B., Cossman, J.S. \& Powers, E.L. 2006, 'Stunted growth is associated with physical indicators of malnutrition but not food insecurity among rural school
children in Honduras', Nutrition Research 26(11), 549-555. http://dx.doi. children in Honduras', Nutrition
org/10.1016/j.nutres.2006.09.009

International Society for the Advancement of Kinanthropometry (ISAK) 2006, International standards for anthropometric assessment, Underdale, SA, Australia.

Jinabhai, C.C., Taylor, M., Coutsodis, A., Coovadia, H.M., Tomkins, A.M. \& Sullivan, K.R., 2001, 'A health and nutritional profile of rural school children in KwaZuluNatal, South Africa', Annals of Tropical Paediatrics 21(1), 50-58. http://dx.doi. org/10.1080/02724930020028920

Kruger, H.S., Steyn, N.P., Swart, E.C., Maunder, E.M., Nel, J.H., Moeng, L. et al., 2012 'Overweight among children decreased, but obesity prevalence remained high among women in South Africa, 1999-2005', Public Health Nutrition 15(4), 594599. http://dx.doi.org/10.1017/S136898001100262X

Labadarios, D., Steyn, N.P., Maunder, E., MacIntryre, R, Gericke, G., Swart, R. et al., 2005, 'The National Food Consumption Survey (NFCS): South Africa, 1999', Public Health Nutrition 8(5), 533-543. http://dx.doi.org/10.1079/PHN2005816

Mendez, M.A. \& Adair, L.S., 1999, 'Severity and timing of stunting in the first two years of life affect performance on cognitive tests in late childhood', The Journal of Nutrition 129(8), 1555-1562.

Monyeki, K.D., Cameron, N. \& Getz, B., 2000, 'Growth and nutritional status of rural South African children 3-10 years old: The Ellisras growth study', American Journal of Human Biology, 12(1), 42-49. http://dx.doi.org/10.1002/(SICI)15206300(200001/02)12:1<42::AID-AJHB6>3.0.CO;2-0

Mukuddem-Petersen, J. \& Kruger, H.S., 2004, 'Association between stunting and overweight among 10-15-y-old children in the North West Province of South Africa: The THUSA BANA Study', International Journal of Obesity and Related Metabolic Disorders 28(7), 842-851. http://dx.doi.org/10.1038/sj.ijo.0802586

Pienaar, A.E., 2009, 'Kinderkinetics: an investment in the total well-being of children', South African Journal for Research in Sport, Physical Education and Recreation 31(1), 49-67. http://dx.doi.org/10.4314/sajrs.v31i1.43792

Popkin, B.M., Richards, M.K. \& Montiero, C.A., 1996, 'Stunting is associated with overweight in children of four nations that are undergoing the nutrition transition', The Journal of Nutrition 126(12), 3009-3016.
Prista, A., Maia, J.A., Damasceno, A. \& Beunen, G., 2003, 'Anthropometric indicators of nutritional status: implications for fitness, activity, and health in school-age children and adolescents from Maputo, Mozambique', American Journal of children and adolescents from
Clinical Nutrition 77(4), 952-959.

Reddy, S.P., Resnicow, K., James, S., Kambaran, N., Omardien, R. \& Mbewu, A.D., 2008, 'Underweight, overweight and obesity among South African adolescents: results of the 2002 National Youth Risk Behaviour Survey', Public Health Nutrition 12(2), 203-207. http://dx.doi.org/10.1017/S1368980008002656

Reis, M., 2012, 'Differences in nutritional outcomes between Brazilian white and black children', Economics \& Human Biology 10(2), 174-188. http://dx.doi. org/10.1016/j.ehb.2011.12.001

Robinson, W.C., Lee, M.K., Hill, K., Hsu, E. \& Burnham, G., 2001, 'Demographic methods to assess food insecurity: A North Korean case study', Prehospital and Disaster Medicine 16(4), 286-292.

Saloojee, H. \& Pettifor, J., 2012, 'Malnutrition', in M. Kibel, T. Westwood \& H. Salojee (eds.), Child health for all: a manual for Southern Africa, 5th edn., pp. 383-396, Oxford University Press, Cape Town.

Saunders, J., Smith, T. \& Stroud, M., 2011, 'Malnutrition and undernutrition', Medicine 39(1), 45-50. http://dx.doi.org/10.1016/j.mpmed.2010.10.007

Scrimshaw, N.S., 1998, 'Malnutrition, brain development, learning and behavior', Nutrition Research 18(2), 351-379. http://dx.doi.org/10.1016/S0271 5317(98)00027-X

Shashidhar, H.R. \& Grigsby, D.G., 2009, Malnutrition, viewed 30 January 2014, from http://emedicine.medscape.com/article/985140-overview\#aw2aab6b2b2

Statsoft, 2011, Statistica for Windows, Release 5.5: General conventions \& statistics, Statsoft, Tulsa, OK

Tharakan, C.T. \& Suchindran, C.M., 1999, 'Determinants of child malnutrition - an intervention model for Botswana', Nutrition Research 19(6), 843-860. http:// dx.doi.org/10.1016/S0271-5317(99)00045-7

Torpy, J.M., Lynm, C. \& Glass, R.M., 2004, 'Malnutrition in children', The Journal of the American Medical Association 292(5), 648. http://dx.doi.org/10.1001/ jama.292.5.648

Triegaardt, J.D., 2005, 'The Child Support Grand in South Africa: a social policy for poverty alleviation?', International Journal of Social Welfare 14(4), 249-255. http://dx.doi.org/10.1111/j.1369-6866.2005.00367.x

United Nations Children's Fund (UNICEF), 1998, The state of the world's children, 1998, viewed 21 April 2011, from http://www.unicef.org/publications/files/pub_ sowc98_en.pdf

United Nations Children's Fund (UNICEF), 2012, The state of the world's children, 2012: children in an urban world, viewed 25 February 2013, from http://www. unicef.org/iran/SOWC_2012-Main_Report_EN_13Mar2012.pdf

Van Stuijvenberg, M.E., 2005, 'Using the school feeding system as a vehicle for micronutrient fortification: experience from South Africa', Food Nutrition Bulletin 26(2 Suppl 2), S213-S219.

Victora, C.G., 1991, 'The association between wasting and stunting: An international perspective', The Journal of Nutrition 122(5), 1105-1110.

Victora, C.G., Adair, L., Fall, C., Hallal, P.C., Martorell, R., Richter, L. et al., 2008, 'Maternal and child undernutrition: consequences for adult health and human capital', Lancet 371(9609), 340-357. http://dx.doi.org/10.1016/S0140-6736(07)61692-4

Vorster, H.H., Oosthuizen, W., Jerling, J.C., Veldman, F.J. \& Burger, H.M., 1997, The nutritional status of South Africans - A review of the literature from 1975-1996, Health Systems Trust, Durban.

Walton, E. \& Allen, S., 2011, 'Malnutrition in developing countries', Paediatrics and Child Nutrition 21(9), 418-424. http://dx.doi.org/10.1016/j.paed.2011.04.004

World Health Organization (WHO), 2005, Malnutrition: Quantifying the health impact at national and local levels, viewed 06 March 2011, from http://www.who.int/ quantifying_ehimpacts/publications/MalnutritionEBD12.pdf?ua=1

World Health Organization (WHO), 2007, WHO reference 2007, viewed 16 April 2012, from http://www.who.int/growthref/en/ 